\title{
Regulation of the ambient conditions for improving heavy metals removal from tanning leather industry waste water by Aspergillus candidus
}

\author{
Eman Fathi Sharaf* and Eman Alharbi \\ Department of Biology, Faculty of Science, Taibah University, AL-Madinah AL- Munawarah, Kingdom of Saudi Arabia. \\ Accepted 26 August, 2013

\begin{abstract}
In the present study, the whole fungal mycelia of Aspergillus candidus, showed the highest capacity for the removal of heavy metals: $\mathrm{Pb}^{+2}, \mathrm{Cu}^{+2}, \mathrm{Fe}^{+3}, \mathrm{Mn}^{+2}, \mathrm{Cr}^{+6}$ and $\mathrm{Sr}^{+2}$ from wastewater effluent of tanning leather industry, compared with the fungal pellets. Maximum biosorption capacity of metals was obtained after using 6 days old biomass and when the process was carried out at $28^{\circ} \mathrm{C}$. Heavy metals sorption was observed at a wide $\mathrm{pH}$ range of the wastewater and particularly increased at slight acidic condition ( $\mathrm{pH} \mathrm{6)}$ for sorption of $\mathrm{Pb}^{+2}$ and $\mathrm{Cu}^{+2}$. However, sorption of $\mathrm{Fe}^{+3}, \mathrm{Mn}^{+2}, \mathrm{Cr}^{+6}$ and $\mathrm{Sr}^{+2}$ was stimulated after adjusting the $\mathrm{pH}$ of the waste water at the alkaline conditions (pH 8 for $\mathrm{Fe}^{3+}$ and $\mathrm{Mn}^{2+}$, and 10 for $\mathrm{Cr}^{6+}$ and $\mathrm{Sr}^{2+}$ ), specially for the last two metals. The results confirm that, the dead biomass of A. candidus offered a great potential as abiosorbent over the living one.
\end{abstract}

Key words: Effluent, Aspergillus candidus, biosorption, $\mathrm{pH}$, heavy metals, dead biomass.

\section{INTRODUCTION}

Disposal of industrial wastewater containing heavy metals has been a major environmental issue. So wastewater should be treated, before disposal, to reduce the concentrations of heavy metals to acceptable or nontoxic levels, particularly because most of them are none or hardly degradable (Bunghez et al., 2010).

Removal of heavy metals from waste waters through biosorption using fungal biomasses is favored green remedies as they have a high level of resistance to metals which make them attractive potential candidates for such purpose (Ezzouhri et al., 2009) .Not only the living biomass but also the dead one can be utilized in the biosorption processes with the latter being more effective in most cases (Pang et al., 2010; Hemambikaet al., 2011).

The successful biosorption processes are greatly affected by the ambient conditions such as $\mathrm{pH}$ and tempera- ture (Javaid et al., 2010; Pang et al., 2010; Kumar et al., 2013), the age of the living cells, the type of metal ions (Kapoor and Viraraghavan, 1995) and others.

Accordingly, the aim of the present work is directed to optimize some of the surrounding conditions for improving the removal of heavy metals from the wastewater effluent of tanning leather industry using $A$. candidus biomass. The biosorption capacity of the dead biomass was also taken into consideration.

\section{MATERIALS AND METHODS}

Fungal culture

The fungal culture $A$. candidus (Code KSA 1500) which showed the highest capacity towards heavy metals sorption from wastewater effluent of tanning leather industry (Sharaf and Alharby, 2013) was used. 


\section{Mycelial mats $\quad$ Fungal pellets}

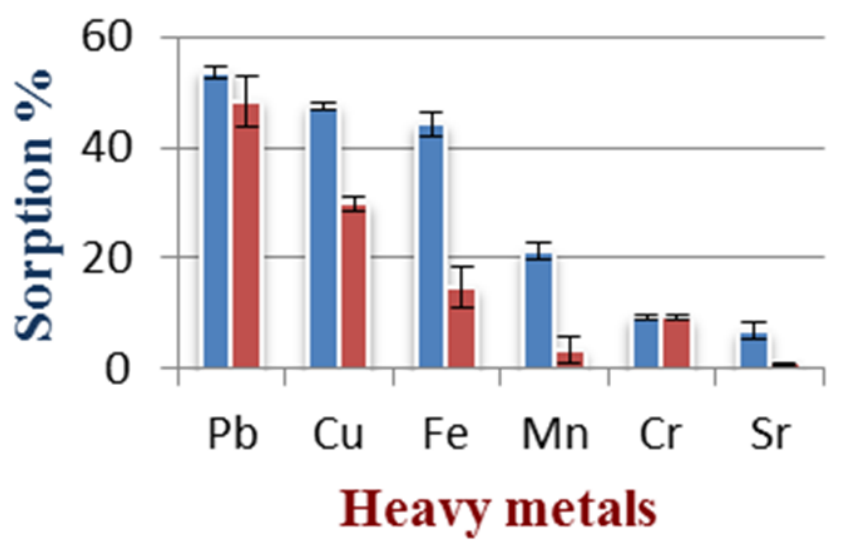

Figure 1. Sorption of heavy metals using $A$. candidus pellet or mycelia. Vertical bars show standard error.

Factors influencing biosorption of heavy metals by $A$.
candidus

\section{Biosorption by fungal pellets or the whole mycelium}

A. candidus was grown in liquid Czapek Dox media and incubated for 7 days under either shaking (125 rpm) to obtain pellets or stationary conditions to get the whole mycelia. The harvested washed fungal mycelia or pellets were used for metal bisorption where $1 \mathrm{~g}$ from each biomass was added separately to flasks $(250 \mathrm{ml}$ capacity) containing $100 \mathrm{ml}$ of the pretreated wastewater (Sharaf and Alharby, 2013). The flasks were incubated under shaking (125 rpm) for $90 \mathrm{~min}$ at $28^{\circ} \mathrm{C}$. After that, the wastewater was filtered and the residual heavy metals content $\left(\mathrm{Cr}^{6+}, \mathrm{Cu}^{2+}, \mathrm{Fe}^{3+}, \mathrm{Mn}^{2+}, \mathrm{Pb}^{2+}, \mathrm{Sr}^{2+}\right)$ was measured, using inductively coupled plasma optical emission spectrometry (ICP-OES) IRIS Intrepid II XDL/Thermo Electron Corporation, at Al-Musa Group for Environmental Laboratories, K.S.A and percentage metal removal was calculated (Sharaf and Alharby, 2013).

\section{Effect of biosorbentage}

Flasks (triplicate) containing sterile Czapek Dox media were inoculated with $A$. candidus culture (7-days old) and were incubated for $3,4,5,6$ and 7 days under static condition to obtain fungal mycelia (the best for biosorption) of different ages. The process of biosorption was performed using these fungal mycelia and percentage metal removal was calculated.

\section{Effect of temperature}

The process of biosorption was conducted at different temperatures of $20,28,35$ and $45^{\circ} \mathrm{C}$ under shaking at $125 \mathrm{rpm}$ for 90 min using A. candidus mycelia of 6 days old (the best biosorbentage). The residual heavy metals in the effluent were estimated.

\section{Effect of effluent $\mathrm{pH}$}

The wastewater effluent was adjusted at different $\mathrm{pH}$ values: 4, 5, $6,7,89$ and 10 using $1.5 \mathrm{M} \mathrm{HCl}$ or $1.0 \mathrm{M} \mathrm{NaOH}$, then inoculated with fungal mycelia and incubated at the optimum temperature $\left(28^{\circ} \mathrm{C}\right)$ for $90 \mathrm{~min}$. After that, the wastewater was filtered and the residual heavy metals were estimated.

\section{Biosorption using dead fungal biomass}

One gram $(1 \mathrm{~g})$ of the fresh biomass of $A$. candidus was dried in oven at $70^{\circ} \mathrm{C}$ till complete dryness. The dried biomass was ground into powder and added to flasks containing the wastewater effluent $(100 \mathrm{ml})$ which was previously adjusted at the optimum $\mathrm{pH}$ for biosorption of each metal ( 6 for $\mathrm{Cu}^{2+}$ and $\mathrm{Pb}^{2+}, 8$ for $\mathrm{Fe}^{3+}$ and $\mathrm{Mn}^{2+}$, and 10 for $\mathrm{Cr}^{6+}$ and $\mathrm{Sr}^{2+}$ ). The flasks were incubated under shaking (125rpm) for $90 \mathrm{~min}$ at optimum temperature $28^{\circ} \mathrm{C}$. After filtration, the percentage metal removal was calculated and the result was compared with the fresh biomass.

\section{Statistical analysis}

Analysis of variance (ANOVA) to determine the significant differences $(P \leq 0.05)$ between means and standard errors using SPSS Statistical Software was applied.

\section{RESULTS AND DISCUSSION}

The result of removal of heavy metals from tanning effluent of leather industry, by $A$. candidus using the whole mycelia or fungal pellets revealed that the metal sorption using the former, which possess a larger surface area, was higher than the latter which have small surface area, except with $\mathrm{Cr}^{+6}$ sorption which showed a non-signi-ficant difference (Figure 1). Similar result was reported by Bakshi et al. (2006). In this connection, Yakubu and Dudeney (1986) stated that the process of biosorption by either fungal pellets or whole biomass is species dependent. The pellets of some species, eventually showed disintegration resulting in an increased resistance to liquid flow and reduced biosorption rate.

In the present work, the gradual increase in the biosorbent age was accompanied by a corresponding increase in the biosorption capacity towards all metals up to 6 days of growth where it reached the maximum. However, progress of age up to the $7^{\text {th }}$ day resulted in a reduction in metals sorption. Similar result was observed by Tahir et al. (2010) and Sarkar et al. (2010). The increase in biosorption rate with increasing biosorbent age might be due to the formation of more cell wall chitin, chitosan and polypeptides which are rich in organic ligands and bind more metals ions (Fletcher and Beckett, 1987).

The current process of metals sorption by $A$. candidus biomass was optimum when carried out at $28^{\circ} \mathrm{C}$; however at higher $\left(45^{\circ} \mathrm{C}\right)$ or lower temperatures $\left(20^{\circ} \mathrm{C}\right)$ a reduction in the sorption capacity was traced. Similar optimum temperature was observed for maximum $\mathrm{Zn}$ removal by Aspergillus fumigatus and A. flavus, (Faryal et al., 2006). In this regard, the temperatures higher than $40^{\circ} \mathrm{C}$ can hinder sorption capability as it affects the integrity of the cell membrane and decrease the attraction force between cell wall and metal ions (Aksu and Kutsal, 1991). Furthermore, the response of the specific metal binding sites towards higher temperature differs from one to another so the overall metal adsorption is affected (Senthilkumar et al., 2007). However, at lower temperatures, the kinetic energy of the metal ions will be reduced which preclude 

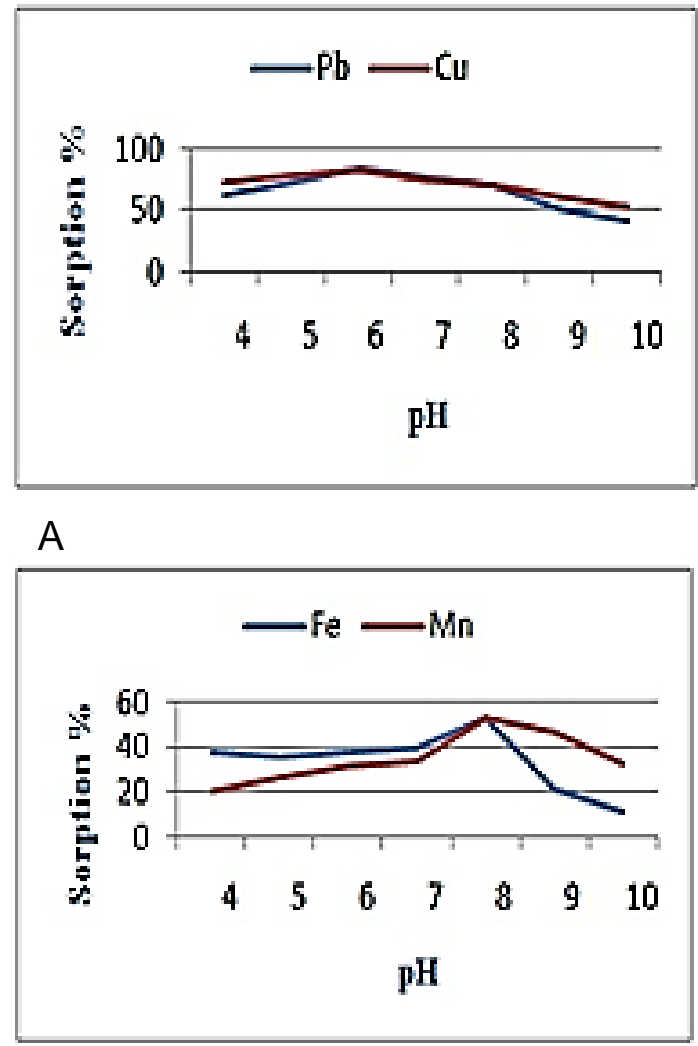

B

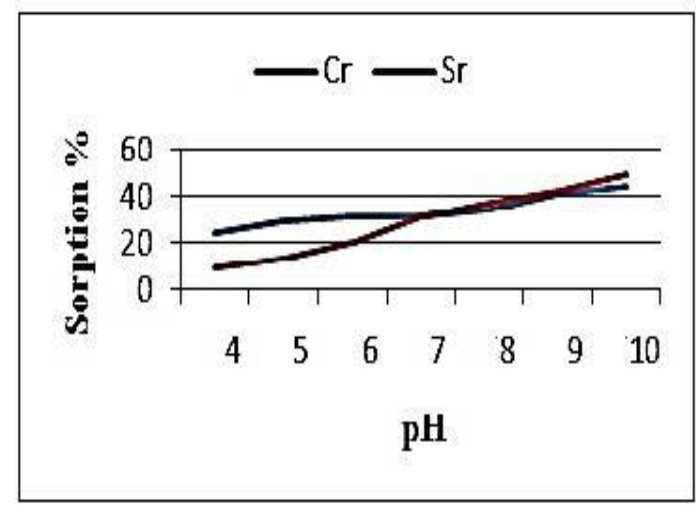

C

Figure 2. Influence of $\mathrm{pH}$ of the wastewater on metals sorption. $\mathrm{A}, \mathrm{Pb}$ and $\mathrm{Cu}$. B, Fe and $\mathrm{Mn}$. C, $\mathrm{Cr}$ and $\mathrm{Sr}$ L.S.D at 5\%: 3.1 .

metal sorption.

On the contrary, the temperature range of $20-45^{\circ} \mathrm{C}$ exhibited no significant influence on biosorption of $\mathrm{Cu}^{2+}$, $\mathrm{Cr}^{6+}, \mathrm{Ni}^{2+}$ and $\mathrm{Zn}^{2+}$ by Schizophyllum commune biomass (Javaidet al.,2010).

In this work, the process of heavy metals sorption from wastewater by $A$. candidus mycelium biomass was greatly influenced by the surrounding $\mathrm{pH}$ (Figure 2a-c). It was observed that the optimum $\mathrm{pH}$ for sorption of metal ions differs from one to another. In this regard, the $\mathrm{pH}$ of the wastewater is the most critical parameter controlling metal removal. It influences: the rate of metal uptake (Banerjee and Nayak, 2007), the competition of metallic ions (Galun et al.,1987), the solubility of metals and the ionization state of the cell wall negatively charged functional groups such as carboxyl and phosphate which act as scavengers for metal ions (Guibal et al.,1995).

It is noteworthy that, the maximum sorption of $\mathrm{Pb}^{2+}$ and $\mathrm{Cu}^{2+}$ was recorded at slight acidic condition( $\mathrm{pH} 6$ ), however at $\mathrm{pH} 7$ and above the metal uptake was reduced (Figure 2a) which might be due to formation of insoluble copper hydroxides which get precipitated and precluded the process (Danis, 2010). Similarly, sorption of $\mathrm{Pb}^{2+}$ by $A$. niveus (Karaca et al., 2010) and $\mathrm{Cu}^{2}$ by Pleurotus cornucopiae (Danis, 2010) was higher at slight acidic pHs. At slight acidic pHs, the negatively charged functional groups become more negative allowing to increase adsorption of $\mathrm{Pb}^{2+}$ and $\mathrm{Cu}^{2+}$ (Danis, 2010).

In the current investigation, $\mathrm{pH} 8$ was optimum for removal of $\mathrm{Fe}^{3+}$ and $\mathrm{Mn}^{2+}$ (Figure 2b). Parvathi et al. (2007) found that, increase in $\mathrm{Mn}$ removal by $A$. niger was correlated with the rise in pH. Diniz and Volesky (2005) suggested that, metal binding increased with increasing $\mathrm{pH}$ due to the decrease of proton concentration which competes for binding sites and/or the reduction in metal solubility which enhances sorption (Tsezos and Volesky, 1982).

The results also revealed that sorption of $\mathrm{Cr}^{6+}$ and $\mathrm{Sr}^{2+}$ ions, favored the alkaline condition and increased with increasing alkalinity (Figure 2c). Sorption was progressively increased with increasing the $\mathrm{pH}$ of the wastewater from 4 up to 10 without an optimum where about 42.7 and $45.4 \%$ of $\mathrm{Cr}^{6+}$ and $\mathrm{Sr}^{2+}$ were adsorbed, respectively. Similar observation was reported (Asaolu and Adefmi, 2012). In this connection, A. clavatus (Das and Santra, 2012) and $A$. terreus (Khani et al., 2012) sorbed more $\mathrm{Cr}$ and $\mathrm{Sr}$ ions under alkaline conditions. At alkaline $\mathrm{pH}$ values even above 10 functional amine groups on the cell surface can be protonated and sorption of chromates occur through electrostatic attraction (Chen et al., 2011).

Oppositely, the optimum $\mathrm{pH}$ for sorption of $\mathrm{Sr}$ by $S$. cerevisiae was 4.5 (Wei et al., 2010) while that for sorption of $\mathrm{Cr}^{2+}$ by $T$. harzianum and $A$. niger was 4 and 2, respectively (Sarkar et al., 2010; Zhong et al., 2011).

A general trend in this study is that the sorption capacity of $A$. candidus towards all metals was very low at $\mathrm{pH}$ 4 where the cell surface became more protonated due to the large number of $\mathrm{H}_{+}$ions which compete with the metal ions for the binding sites so impeding adsorption (Chen et al., 2011).

At this stage of our study, it is urged to compare the biosorption capacity of the living biomass of $A$. candidus with that of the dead one under the previously mentioned optimum conditions (Figure 3). In general, the process of biosorption of heavy metals by dead biomass exceeded that by the living one, except for $\mathrm{Fe}^{3+}$ ions where the process was almost similar with both biomasses. In this regard, the dead biomass does not suffer from metal toxi- 


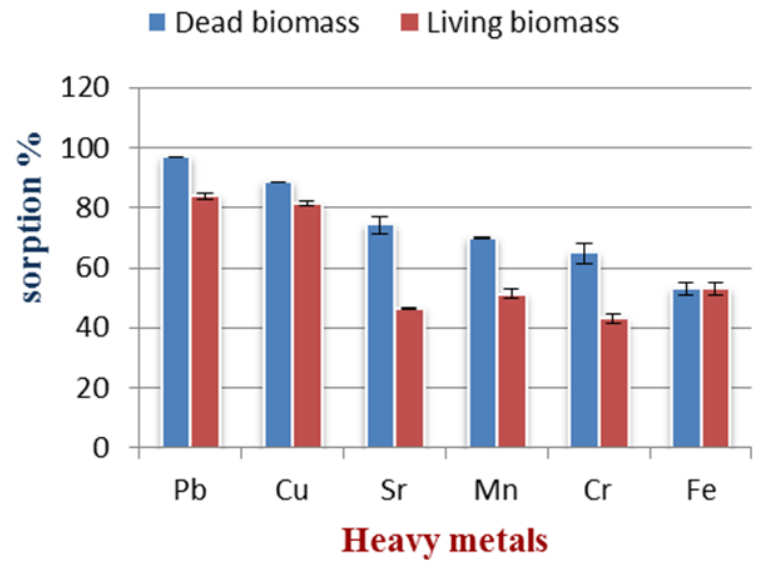

Figure 3. Sorption of heavy metals using living or dead biomass of $A$. candidus. Vertical bars show standard error.

city and it my act as a colloidal system which have more active sites for metal sorption. In addition, the cell membrane of the living cells can interfere and control the adsorption and/or absorption of certain metal ions according to the cell demand.

In the view of the other recent studies, dead biomass of Penicillium citrinum (Pang et al., 2010) and A. niger (Issac and Prabha, 2011) achieved extra sorption than the living biomass for removal of uranium and $\mathrm{Cr}^{2+}$ from aqueous solution, respectively. In addition, the dead fungal cells of Aspergillus sp., Penicillium sp. and Cephalosporium sp. were used for efficient removal of $\mathrm{Cu}, \mathrm{Cd}$ and $\mathrm{Pb}$ from industrial wastewaters, respectively (Hemambika et al., 2011).

\section{Conclusion}

The findings in this study suggest that, optimization of surrounding conditions, particularly the $\mathrm{pH}$ of the waste water, enhances sorption of heavy metals. Efficiency of the dead biomass $A$. candidus encourages its use as cheap, natural non pollutant green remedy in the biosorption processes.

\section{REFERENCES}

Aksu Z, Kutsal TA (1991). Abioseparation process for removing $\mathrm{Pb}^{2+}$ ions from wastewater by using C.vulgaris. J. Chem. Technol. Biotechnol. 52:108-118.

Asaolu SS, Adefemi OS (2012).Adsorption of metals ions on clay sample as a function of pH. J. Int. Environ. Appl. Sci. 7: 446-450.

Bakshi D, Saha S, Sindhu I, Sharma P (2006). Use of Phanerochaetechry sosporium biomass for the removal of textile dyes from a synthetic effluent.W. J. Micro Biotechnol. 22:835-839.

Banerjee A, Nayak D (2007). Biosorption of no-carrier-added radionuclides by calcium alginate beads using 'tracer packet' technique. Biores. Technol. 98: 2771- 2774.

Bunghez I, Ion R, Dumitriu I, Fierascu R (2010). Heavy metal ions depollution by marine natural products. J. Sci. Arts. 1:73-78.

Chen G, Zhang W, Zeng G, Huang J, Wang L, Shen G (2011). Surfacemodified Phanerochaetechrysosporium as a biosorbent for $\mathrm{Cr}(\mathrm{VI})$ contaminated wastewater. J. H. Mat. 186:2138-214.
Danis $U$ (2010). Biosorption of $\mathrm{Cu}^{+2}$ from Aqueous Solutions by Pleurotuscornucopiae.Desal. Wat. Treat. 22: 117-126.

Das S, Santra SC (2012). Bio-detoxification of chromium from industrial wastewater by fungal strains. Biol. 58:1-6.

Diniz V, Volesky B (2005). Biosorption of $\mathrm{La}$, Eu and $\mathrm{Yb}$ using Sargassam biomass. Wat. Res. 39:239-247.

Ezzouhri L, Castro E, Moya M, Espinola F, Lairini K (2009). Heavy metal tolerance of filamentous fungi isolated from polluted sites in Tangier, Morocco. Afr. J. Microbiol. Res. 3:035-048.

Faryal R, Lodhi A, Hameed A (2006). Isolation, characterization and biosorption of Zinc by indigenous fungal strains Aspergillusfumigatus rh05 and Aspergillusflavus rh07. Pak. J. Bot. 38:817-832.

Fletcher P, Beckett P (1987). The chemistry of heavy metals in digested sewage sludge-II. Heavy metal complexation with soluble organic matter.Wat. Res. 21:1163-1172.

Galun M, Galun E, Siegel BZ, Keller P, Lehr H (1987). Removal of metal ions from aqueous solutions by Pencillium biomass: Kinetic and uptake parameters. Wat. Air Soil. Pollut. 33:359-371.

Guibal E, Roulph C, Le Cloirec P (1995).Infrared spectroscopic study of uranyl biosorption by fungal biomass and materials of biological origin. Environ. Sci. Technol. 29: 2496-2503.

Hemambika B, Rani MJ, Kannan VR (2011).Biosorption of heavy metals by immobilized and dead fungal cells: A comparative assessment. J. Ecol. Nat. Environ. 3:168-175.

Isaac I, prabha $L$ (2011). Equilibrium and kinetic studies on biosorption of $\mathrm{Cr}(\mathrm{VI})$ by non-living mycelial suspensions of Aspergillus niger. Int. J. Pharma. Biol. Sci. 2: 213-222.

Javaid A, Bajwa R, Javaid A (2010).Biosorption of heavy metals using a dead macro fungus Schizophyllumcommunefries: evaluation of equilibrium and kinetic models. Pak. J. Bot. 42:2105-2118.

Kapoor A, Viraraghavan T (1995). Fungalbiosorption-an alternative treatment option for heavy metal bearing wastewaters: a review. Biores. Technol. 53:195-206.

Karaca H, Tay T, Kivanc M (2010). Kinetics of lead ion biosorption from aqueous solution onto lyophilized Aspergillusniveus. Wat.Pract. Technol. 5:1-10.

Khani MH, Pahlavanzadeh MH, Alizadeh K (2012).Biosorption of strontium from aqueous solution by fungus Aspergillusterreus. Environ. Sci. Pollut. Res. 19:2408-2418.

Kumar M, Pal A, Singh J, Garg S, Bala M, Vyas A, Khasa Y, Pachouri U (2013).Removal of chromium from water effluent by adsorption onto Vetiveriazizanioides and Anabaena species. N. Sci. 5: 341-348. doi: 10.4236/ns.2013.53047.

Pang C, Liu Y, Cao X, Li M, Huang G, Hua R, Wang C, Liu Y, Fu An, X (2010). Biosorption of uranium ( $\mathrm{VI}$ ) from aqueous solution by dead fungal biomass of Penicilliumcitrinum. Chem. Eng. J. 37:1-30.

Parvathi K, Kumar RN, Nagendran R (2007).Biosorption of manganese by Aspergillusniger and Saccharomyces cerevisiae. W. J. Microbiol. Biotechnol. 23:671-676.

Sarkar S, Satheshkumar A, Pradeepa N, Premkumar R (2010). Hexavalent chromium $\left(\mathrm{Cr}^{+3}\right)$ removal by live mycelium of a Trichodermaharzianum strain. Asian. J. Exp. Biol. Sci. 1: 606-613.

Senthilkumar R, Vijayaraghavan K, Thilakavathi M, Iyer PV, Velan M (2007). Application of seaweeds for the removal of lead from aqueous solution. Biochem. Eng. J. 33:211-216.

Sharaf EF, Alharby EA (2013). Removal of heavy metals from waste water of tanning leather industry by fungal species isolated from polluted soil, a green remedy. Afr. J. Biotechnol. 12:4351-4355.

Tahir A, Zahid S, Mateen B, Farasat T, Mughal T (2010).Optimization of cultural conditions for the propagation of Gliocladiumviridezic2063 as potential biosorbent. J. Appl. Pharma. 1: 37-46.

Tsezos M, Volesky B (1982). The mechanism of uranium biosorption by Rhizopusarrhizus. Biotechnol. Bioeng. 24:385-401.

Wei Z, Faqin D, Qunwei D (2010).Biosorption of Strontium lons in Aqueous Solution by Beer Yeast.Bioinformatics and Biomedical Engineering. Lab. of Solid Waste Treat. Res. Recycle.Mianyang, China.

Yakubu NA, Dudeney AW (1986). Biosorption of uranium with Aspergillus niger. In: Eccles $\mathrm{HH}$, Hunt S (eds) Immobilizations of Ions by Biosorption. Chichester, UK, Ellis, Horwood, pp. 183-200.

Zhong L, Dai S, Chen Y (2011). Biosorption of $\mathrm{Cr}(\mathrm{VI})$ from Aqueous Solution by Aspergillus niger. J. Adv. Mat. Res. 236-238:155-158. 